\title{
Microscale Thermophoresis Reveals Oxidized Glutathione as High-Affinity Ligand of Mal d 1
}

\author{
Soraya Chebib and Wilfried Schwab *(D) \\ Biotechnology of Natural Products, Technical University Munich, Liesel-Beckmann-Str. 1, \\ 85354 Freising, Germany; soraya.chebib@tum.de \\ * Correspondence: wilfried.schwab@tum.de; Tel.: +49-8161712912
}

check for updates

Citation: Chebib, S.; Schwab, W. Microscale Thermophoresis Reveals Oxidized Glutathione as HighAffinity Ligand of Mal d 1. Foods 2021, 10, 2771. https://doi.org/10.3390/ foods10112771

Academic Editors: Sara Benedé and Daniel Lozano-Ojalvo

Received: 5 October 2021

Accepted: 9 November 2021

Published: 11 November 2021

Publisher's Note: MDPI stays neutral with regard to jurisdictional claims in published maps and institutional affiliations.

Copyright: (c) 2021 by the authors. Licensee MDPI, Basel, Switzerland. This article is an open access article distributed under the terms and conditions of the Creative Commons Attribution (CC BY) license (https:// creativecommons.org/licenses/by/ $4.0 /)$.

\begin{abstract}
Pathogenesis-related (PR)-10 proteins, due to their particular secondary structure, can bind various ligands which could be important for their biological function. Accordingly, the PR10 protein Mal d 1, the major apple allergen, probably also binds molecules in the hydrophobic cavity of its secondary structure, but it has not yet been investigated in this respect. In this study, various natural products found in apples such as flavonoids, glutathione (GSH), and glutathione disulfide (GSSG) were investigated as possible ligands of Mal d 1 using microscale thermophoresis. Dissociation constants of $16.39 \mu \mathrm{M}, 29.51 \mu \mathrm{M}, 35.79 \mu \mathrm{M}$, and $0.157 \mu \mathrm{M}$ were determined for catechin, quercetin-3-O-rhamnoside, GSH, and GSSG, respectively. Molecular docking was performed to better understand the underlying binding mechanism and revealed hydrophobic interactions that stabilize the ligands within the pocket while hydrophilic interactions determine the binding of both GSH derivatives. The binding of these ligands could be important for the allergenicity of the PR-10 protein and provide further insights into its physiological role.
\end{abstract}

Keywords: Mal d 1; ligand; glutathione

\section{Introduction}

In North America, and Central and Northern Europe, most immediate allergic reactions are triggered by pollen and food allergens of the Bet $\mathrm{v} 1$ family, named after the major pollen allergen of white birch (Betula verrucosa), which causes seasonal allergies. The structural Bet v 1 homologue Mal d 1 is one of the major allergens in apple (Malus domestica L. Borkh), and causes immunological cross-reactions in Bet v 1 sensitized patients [1]. Sensitization to Mal d 1 is associated with symptoms ranging from mild and local allergic reactions (oral allergy syndrome) to severe reactions such as anaphylactic shock [2]. Since Mal d 1 is a heat labile and protease sensitive protein, the allergic potential can be altered by various processing procedures such as heating [3-5]. Mal d 1 belongs to the family of pathogenesis-related (PR)-10 proteins and their expression is induced by various environmental conditions including pathogens (e.g., bacteria, fungi), wounding, UV light, and chemicals [6]. However, PR-10 proteins are also constitutively expressed in certain plant development stages [7] and they occur in a variety of different isoforms, caused by gene duplication or by recombinant coding of multiple genes [8]. The characteristic PR-10 fold consists of a seven-stranded antiparallel $\beta$-sheet, two short $\alpha$-helices in V-shapes, and a long C-terminal $\alpha$-helix [9]. The arrangement of these secondary structural elements creates a large, solvent accessible hydrophobic cavity capable of binding hydrophobic ligands [10]. The affinity properties between a protein and different interaction partners can have a significant impact on its biological activity. However, the biological function of Mal d 1 and other PR-10 proteins is still poorly understood [10]. The sequence homology of PR-10 proteins with ribonucleases from ginseng callus suggested ribonuclease activity for the entire protein family that could be affected by phosphorylation [11,12]. Multiple studies revealed the binding of several hydrophobic ligands such as cytokinins, phytosteroids, and flavonoid glycosides to members of the Bet $\mathrm{v} 1$ family, suggesting binding, transport, and 
storage functions of the protein family (Table 1) [13-17]. Phytosteroid binding was reported for Pru av1, the homologue protein in cherry [18], but was also suggested for Bet $\mathrm{v} 1$ as both proteins show high structural similarity to the START domain of the human protein MLN64, that is considered to be a cholesterol transfer protein [19]. The crystal structure of Bet $\mathrm{v} 1$ isoforms a and 1 could be elucidated as complexes with 1-anilino-8-naphthalene sulfonate (ANS) and with the buffer steroid deoxycholate, respectively [20,21]. In addition, Bet $\mathrm{v} 1$ has the ability to bind and permeabilize membranes, suggesting a mechanism for sensitization by and the allergic response of Bet $\mathrm{v} 1$ [22].

Table 1. Identified ligands of PR-10 proteins.

\begin{tabular}{|c|c|c|c|c|c|}
\hline Plant & Protein & Ligand & $\mathbf{K d}[\mu \mathbf{M}]$ & Method & References \\
\hline \multirow[t]{21}{*}{ Birch } & Bet v 1a & ANS & 18.5 & NMR, Fluorescence & {$[20,23]$} \\
\hline & & Deoxycholate & 58.8 & NMR, SAW & {$[20,24]$} \\
\hline & & Quercetin & 31.4 & NMR & {$[14,25]$} \\
\hline & & & 9.2 & UV/VIS & {$[14,25]$} \\
\hline & & Quercetin-3-O-sophoroside & 0.57 & Fluorescence & {$[14,25]$} \\
\hline & & Quercetin-3-O-galactoside & $<5$ & NMR & [25] \\
\hline & & Quercetin-3-O-glucoside & 288.4 & NMR & [25] \\
\hline & & Fisetin & 14.3 & UV/VIS & [25] \\
\hline & & Myricetin & 14.6 & NMR & [25] \\
\hline & & Naringenin & 60.6 & UV/VIS & [25] \\
\hline & Bet $\mathrm{v} 1 \mathrm{~m}$ & Quercetin & 65.8 & NMR & [25] \\
\hline & & & 26.5 & UV/VIS & [25] \\
\hline & & Quercetin-3-O-galactoside & $<5$ & NMR & [25] \\
\hline & & Quercetin-3-O-glucoside & $<5$ & NMR & [25] \\
\hline & & Fisetin & 68.6 & UV/VIS & [25] \\
\hline & & Myricetin & 99.3 & NMR & [25] \\
\hline & & Naringenin & 28.1 & UV/VIS & [25] \\
\hline & Bet $\mathrm{v} 1 \mathrm{~d}$ & Quercetin & 10.2 & UV/VIS & [25] \\
\hline & & Fisetin & 13.9 & UV/VIS & [25] \\
\hline & & Myricetin & 1.2 & UV/VIS & [25] \\
\hline & & Naringenin & 37.7 & UV/VIS & {$[25]$} \\
\hline \multirow[t]{3}{*}{ Strawberry } & Fra a $1 \mathrm{E}$ & Quercetin-3-O-glucuronide & 5.3 & ITC & [13] \\
\hline & Fra a 2 & Myricetin & 19.5 & ITC & [13] \\
\hline & Fra a 3 & $(+)$-Catechin & 8.9 & ITC & [13] \\
\hline Hazelnut & Cor a 1 & $\begin{array}{l}\text { Quercetin-3-O-(2-O- } \beta \text {-D- } \\
\text { glucopyranosyl)- } \beta-\mathrm{D}- \\
\text { galactopyranoside }\end{array}$ & $<5$ & NMR & [26] \\
\hline Peach & Pru p 1.0101 & Zeatin & 9.4 & ITC & [27] \\
\hline
\end{tabular}

The aim of this study was to explore for the first time the interaction of recombinant rMal d 1.02 and various potential ligands using microscale thermophoresis (MST). The MST instrument detects a change in the fluorescence signal along a temperature gradient induced by an infrared laser [28]. The thermophoresis of the fluorescent target protein is different from that of the protein-ligand complex as the binding event results in changes of the hydration shell, charge, and/or size. An equilibrium dissociation constant $\left(\mathrm{K}_{\mathrm{d}}\right)$ can be determined by using a dilution series of, usually, 16 MST measurements with a constant amount of fluorescent binding partner and increasing amounts of nonfluorescent ligand. We were able to identify for the first time a high affinity interaction between our target protein rMal d 1.02 and oxidized glutathione (GSSG). We further detected the binding of reduced glutathione (GSH; $\gamma$-Glu-Cys-Gly), (+)-catechin, (+/-)-epicatechin, and quercetin-3-O-rhamnoside. Molecular docking was used to investigate the underlying interaction mechanism. 


\section{Materials and Methods}

\subsection{Chemicals}

The chemicals were purchased from Carl Roth (Karlsruhe, Germany), Sigma-Aldrich (Taufkirchen, Germany), and Merck (Darmstadt, Germany), unless otherwise stated in the text. The reference substances quercetin-3-O-rhamnoside and (+)-epicatechin were obtained from our in-house standard reference library.

\subsection{Production and Purification of Recombinant rMal $d 1$}

Recombinant rMal d 1 was produced in E. coli BL21 (DE3) pLysS, as previously described [29]. A single colony was inoculated into $25 \mathrm{~mL}$ of LB medium, containing $100 \mu \mathrm{g} / \mathrm{mL}$ ampicillin and $34 \mu \mathrm{g} / \mathrm{mL}$ chloramphenicol. Cells were cultured overnight at $37^{\circ} \mathrm{C}$ under constant shaking. Fifteen $\mathrm{mL}$ overnight culture was inoculated into fresh LB medium $(1 \mathrm{~L})$ with respective antibiotics $(100 \mu \mathrm{g} / \mathrm{mL}$ ampicillin, $34 \mu \mathrm{g} / \mathrm{mL}$ chloramphenicol). Cells were grown at $37^{\circ} \mathrm{C}$ to an optical density (OD) of 0.6 , and protein expression was induced with isopropyl- $\beta$-D-1-thiogalactopyranoside (IPTG; $100 \mu \mathrm{g} / \mathrm{mL}$ ) at $18{ }^{\circ} \mathrm{C}$ overnight. The suspension was centrifuged $\left(15 \mathrm{~min}\right.$ at $4^{\circ} \mathrm{C}$ and $\left.5000 \times g\right)$. Pellets were frozen at $-80{ }^{\circ} \mathrm{C}$ for $30 \mathrm{~min}$ and resuspended in binding buffer $(50 \mathrm{mM}$ Tris, $220 \mathrm{mM}$ $\mathrm{NaCl}, 10 \mathrm{mM}$ imidazole, $\mathrm{pH}$ 7.5) containing $0.5 \mathrm{mM}$ phenylmethylsulfonyl fluoride (PMSF), $1 \mathrm{mM} \mathrm{MgCl}_{2}$ (New England Biolabs, Frankfurt, Germany), $1 \mu \mathrm{L}$ DNAse and $0.5 \mathrm{mg} / \mathrm{mL}$ lysozyme, followed by cell disruption using ultrasonication $(3 \times 1 \mathrm{~min}$, cycle $5 \times 10 \%, 50 \%$ power). The soluble protein fraction was applied onto a column containing His-Tag resin (Bio-Rad Laboratories, Feldkirchen, Germany) and incubated overnight at $4{ }^{\circ} \mathrm{C}$. The soluble protein fraction was purified by Profinity Immobilized Metal Ion Affinity Chromatography (IMAC) using $10 \mathrm{mM}$ to $250 \mathrm{mM}$ imidazole. The purified fractions were dialyzed against sodium carbonate buffer (10 $\left.\mathrm{mM} \mathrm{Na}_{2} \mathrm{CO}_{3}, 10 \mathrm{mM} \mathrm{NaHCO}_{3}, \mathrm{pH} 9\right)$, lyophilized, and stored at $-20{ }^{\circ} \mathrm{C}$ until further use. Protein was resuspended in PBS buffer $(150 \mathrm{mM} \mathrm{NaCl}, 10 \mathrm{mM}$ $\mathrm{Na}_{2} \mathrm{HPO}_{4}$, pH 7.4 adjusted by $10 \mathrm{mM} \mathrm{NaH} \mathrm{PO}_{4}$ ) and incubated at $4{ }^{\circ} \mathrm{C}$ for at least $2 \mathrm{~h}$ prior to analysis. Protein concentrations were measured by UV/Vis spectrometry using an extinction coefficient of 0.849 [30,31].

\subsection{Microscale Thermophoresis}

The protein rMal d 1 was labeled using the His-Tag labeling kit RED-tris-NTA 2nd Generation (Nanotemper Technologies GmbH, Munich, Germany). The labeling was performed according to the protocol provided by the manufacturer. Proteins were diluted to the final concentration of approximately $960 \mathrm{nM}$ in PBS-T buffer (150 mM NaCl, $10 \mathrm{mM}$ $\mathrm{Na}_{2} \mathrm{HPO}_{4}$, pH 7.4, adjusted by $10 \mathrm{mM} \mathrm{NaH} \mathrm{PO}_{4}, 0.05 \%$ Tween 20). RED-tris-NTA was diluted in PBS-T to a final concentration of $100 \mathrm{nM}$. Then, $90 \mu \mathrm{L}$ of protein $(\sim 960 \mathrm{nM})$ was mixed with $90 \mu \mathrm{L}$ of dye $(100 \mathrm{nM})$. The mixture was incubated on ice for $30 \mathrm{~min}$ in the dark. The sample was centrifuged for $10 \mathrm{~min}$ at $4{ }^{\circ} \mathrm{C}$ and $15,000 \times g$ and the supernatant transferred to a fresh tube. MST measurements were performed with rMal $\mathrm{d} 1$ and the following substances: reduced glutathione (GSH), oxidized glutathione (GSSG), glycine, glutamic acid, quercetin-3-O-rhamnoside, (+)-catechin, and (+/-)-epicatechin. GSH, GSSG, glycine, and glutamic acid were dissolved in PBS buffer, while quercetin-3-O-rhamnoside was dissolved in carbonate/bicarbonate buffer ( $30 \mathrm{mM} \mathrm{Na} 2 \mathrm{CO}_{3}, 70 \mathrm{mM} \mathrm{NaHCO}, \mathrm{pH}$ 9.6). (+)-Catechin and (+/-)-epicatechin were dissolved in DMSO. All ligands were further diluted in PBS-T; organic solvent concentrations in each assay were kept below $5 \%$. A total of 16x 1:1 ligand dilutions in an end volume of $10 \mu \mathrm{L}$ were prepared in PBS-T buffer. The final concentration ranged for GSSG from $100 \mu \mathrm{M}$ to $3.05 \mathrm{nM}$ and from $500 \mu \mathrm{M}$ to $15.25 \mathrm{nM}$; for GSH, (+)-catechin and (+/-)-epicatechin from $0.001 \mu \mathrm{M}$ to $30.52 \mathrm{nM}$; for quercetin-3-Orhamnoside from $500 \mu \mathrm{M}$ to $15.25 \mathrm{nM}$. The amino acids glutamic acid and glycine were used in a concentration range from $12 \mathrm{mM}$ to $366 \mathrm{nM}$ and $24.29 \mathrm{mM}$ to $741.27 \mathrm{nM}$, respectively. Ten $\mu \mathrm{L}$ of labeled rMal d 1 was added to all dilutions. Reactions were incubated on ice for at least $30 \mathrm{~min}$ and then loaded into Monolith NT.115 capillaries. All measurements were carried out with a Monolith NT.115 device (Nanotemper Technologies GmbH, Munich, 
Germany), using the MO.Control software v1.6.1, at $60 \%$ LED and high MST power. In each analysis, it was ensured that the intensity of the fluorescent target molecule was above $>200$ counts with variations $<20 \%$ and that no protein aggregation occurred. Data was analyzed using MO.Affinity analysis software v2.3 (Nanotemper Technologies GmbH, Munich, Germany). Single outliers were removed from the performed technical replicates if it greatly lowered the standard deviation of the determined $K_{d}$. For GSSG, two technical replicates for each concentration range were independently pipetted and the measurements were analyzed using the signal from MST-on time of 20 s. For GSH and quercetin-3-Orhamnoside, four and three technical replicates, respectively, were measured and analyzed using the signal from MST-on time of 10s. Three replicates of catechin were measured and analyzed using the signal from MST-on time of $20 \mathrm{~s}$. (+)-Epicatechin and (-)-epicatechin, each analyzed in triplicates, were evaluated at an MST-on time of $20 \mathrm{~s}$ and $2.5 \mathrm{~s}$, respectively. Glutamic acid and glycine were analyzed by a single run at an MST-on time of $20 \mathrm{~s}$. The MST-on time, which yields a signal-to-noise ratio $>6$ in the binding curve, was used to determine the dissociation constant $\left(\mathrm{K}_{\mathrm{d}}\right)$. According to the manufacturer's protocol, GSH interferes with the labeling dye at concentrations above $10 \mathrm{mM}$. Control experiments with a labeled control peptide (His6 peptide; provided by the manufacturer) and GSH, GSSG, and cysteine were performed to analyze possible interactions with the labeling dye. The lyophilized control peptide was suspended and further diluted in PBST-T to a final concentration of $200 \mathrm{nM}$. RED-tris-NTA was diluted in PBS-T to a final concentration of $100 \mathrm{nM}$. Then, $90 \mu \mathrm{L}$ of the peptide $(200 \mathrm{nM})$ was added to $90 \mu \mathrm{L}$ of the dye $(100 \mathrm{nM})$ and incubated for $30 \mathrm{~min}$ in the dark. A 16x 1:1 dilution series was prepared as described above. The final concentration for GSH and cysteine ranged from $0.001 \mu \mathrm{M}$ to $30.52 \mathrm{nM}$ and for GSSG from $0.002 \mu \mathrm{M}$ to $61.04 \mathrm{nM}$. GSH, cysteine, and GSSG were analyzed in a single run at an MST-on time of $5 \mathrm{~s}, 5 \mathrm{~s}$ and $1.5 \mathrm{~s}$, respectively. The $\mathrm{K}_{\mathrm{d}}$ was calculated by Equation (1) according to the law of mass action, where $\mathrm{f}$ (conc) is the fraction bound at a given ligand concentration; Unbound is the response value of the unbound state; Bound is the response value of the bound state; TargetConc is the final concentration of the labeled molecule (https: / www.manualslib.com/manual/1556718/Nano-Temper-Monolith-Nt115.html; accessed on 10 November 2021).

$\mathrm{f}($ conc $)=$ Unbound $+\frac{(\text { Bound }- \text { Unbound }) \times\left(\text { Conc }+ \text { TargetConc }+K_{d}-\sqrt{\left(\text { Conc }+ \text { TargetConc }+K_{d}\right)^{2}-4 \times \text { Conc } \times \text { TargetConc }}\right.}{2 \times \text { TargetConc }}$

\subsection{Molecular Docking}

For molecular docking, AutoDock Vina v1.1.2 (http: / / vina.scripps.edu/; accessed on 22 September 2021) [32] was used to dock the ligands GSSG, GSH, (+)-catechin, $(+/ \times)$ epicatechin, and quercetin-3-O-rhamnoside into the hydrophobic pocket of rMal d 1.02. The recombinant protein was modeled using SWISS-MODEL (https:/ / swissmodel.exp asy.org/interactive; accessed on 26 July 2021). Input files of rMal d 1 and ligand were created with AutoDockTools v1.5.6 (http: / / autodock.scripps.edu/resources/adt; accessed on 22 September 2021). The protein structure was prepared for molecular docking by removing all water molecules, computing Kollman charges, and adding polar hydrogens. The hydrophobic pocket of the protein was obtained by BiteNet (https://sites.skoltech .ru/imolecule/tools/bitenet; accessed on 4 August 2021) [33]. The grid box (36/36/34) was placed over the hydrophobic pocket of the protein. AutoDockVina was run by default settings and generated nine possible conformations of the ligand in complex with rMal d 1. Only the ligand conformation with the highest calculated affinity to the protein is presented. Binding energies $(\Delta G)$ were used to calculate an equilibrium $\mathrm{K}_{\mathrm{d}}$ by Equation (2) with $\mathrm{R}=1.986 \mathrm{cal} / \mathrm{mol}^{*} \mathrm{~K}$ and $\mathrm{T}=298.15 \mathrm{~K}$ [14]. The resulting models were visualized by Discovery Studio v21.1.0.20298 (https: / / discover.3ds.com/discovery-studio-visualizer-d ownload; accessed on 22 September 2021).

$$
\mathrm{K}_{\mathrm{d}}=\mathrm{e}^{-\frac{\Delta \mathrm{G}}{\mathrm{R} \times \mathrm{T}}}
$$




\section{Results}

\section{1. rMal d 1.02 in Complex with Flavonoids}

Although the ligand-binding ability of several PR-10 proteins has been recently analyzed (Table 1), Mal d 1 has not been evaluated for this property until now. Since PR10 proteins are known to bind flavonoids, we selected similar metabolites that occur naturally in apples, namely quercetin-3-O-rhamnoside, $(+)$-catechin, and $(+)$ and $(-)-$ epicatechin as potential candidates for MST binding assays [34]. All binding assays were exclusively carried out using the recombinant rMal d 1 . The results of the MST experiments show that these natural flavonoids bind to rMal d 1 with different affinities (Figure 1a,b; Supplementary Figure S1a,b). (+)-Catechin and quercetin-3-O-rhamnoside exhibit affinities in the low micromolar range with $K_{d}$ values of $16.39 \pm 5.35 \mu \mathrm{M}$ and $29.51 \pm 7.75 \mu \mathrm{M}$, respectively (Figure 1a,b). The enantiomers (+)-epicatechin and (-)-epicatechin bind in the higher $\mu \mathrm{M}$ range with $\mathrm{K}_{\mathrm{d}}$ values of $152.53 \pm 31.03 \mu \mathrm{M}$ and $663.88 \pm 393.46 \mu \mathrm{M}$, respectively (Supplementary Figure S1a,b). Both binding curves do not reach saturation in the bound state, and thus the $K_{d}$ values show higher standard deviations. The $S / N$ of the experiments was above 10, indicating excellent assay conditions and good data quality. In general, the MST experiments showed some variations between the individual technical replicates. This could be due to the occurrence of additional specific or nonspecific binding events that may have directly affected the binding affinity of a compound to the protein. Previous crystallographic studies of other PR-10 proteins reported the binding of additional ligands outside of the pocket, at intermolecular sites [35].

\section{2. rMal 1 Binds Glutathione in Both Reduced and Oxidized Forms with Different Specificities}

In addition to flavonoids, we studied the binding behavior of GSH and GSSG to Mal $\mathrm{d} 1$, as apple is a rich source of GSH [36]. MST experiments revealed specific interactions between rMal $\mathrm{d} 1$ and GSH, as well as rMal d 1 and GSSG. GSH binds to rMal $\mathrm{d} 1$ with a $\mathrm{K}_{\mathrm{d}}$ of $35.79 \pm 12.76 \mu \mathrm{M}$ (Figure 1c). The binding of GSSG to rMal d 1 was evaluated by two concentration ranges, of which the dose response curve with $500 \mathrm{nM} \mathrm{GSSG}$ as the highest concentration led to a $\mathrm{K}_{\mathrm{d}}$ of $0.480 \pm 0.163 \mu \mathrm{M}$ (Figure 1d), whereas the binding curve with $100 \mathrm{nM}$ GSSG as the highest concentration provided a $\mathrm{K}_{\mathrm{d}}$ of $0.157 \pm 0.087 \mu \mathrm{M}$ (Figure 1e). The latter showed an even equilibrium between the bound and unbound state, and thus resulting in a more accurate $K_{d}$ with lower standard deviation. Furthermore, the affinity of the individual amino acids (glycine, glutamic acid, and cysteine), present in GSH, to rMal d 1 was investigated to clarify whether there is a specificity for the entire molecule or only for certain amino acids. The binding of cysteine could not be investigated, as the ligand interfered with the His labeling dye (Supplementary Figure S2a). Interferences between the dye and GSH and GSSG were not observed (Supplementary Figure S2b,c). No binding was detected for glutamic acid, and only a weak interaction was observed for glycine and rMal d 1 (Supplementary Figure S1c,d), indicating that the binding of GSSG and GSH to rMal $\mathrm{d} 1$ is specific. 
a
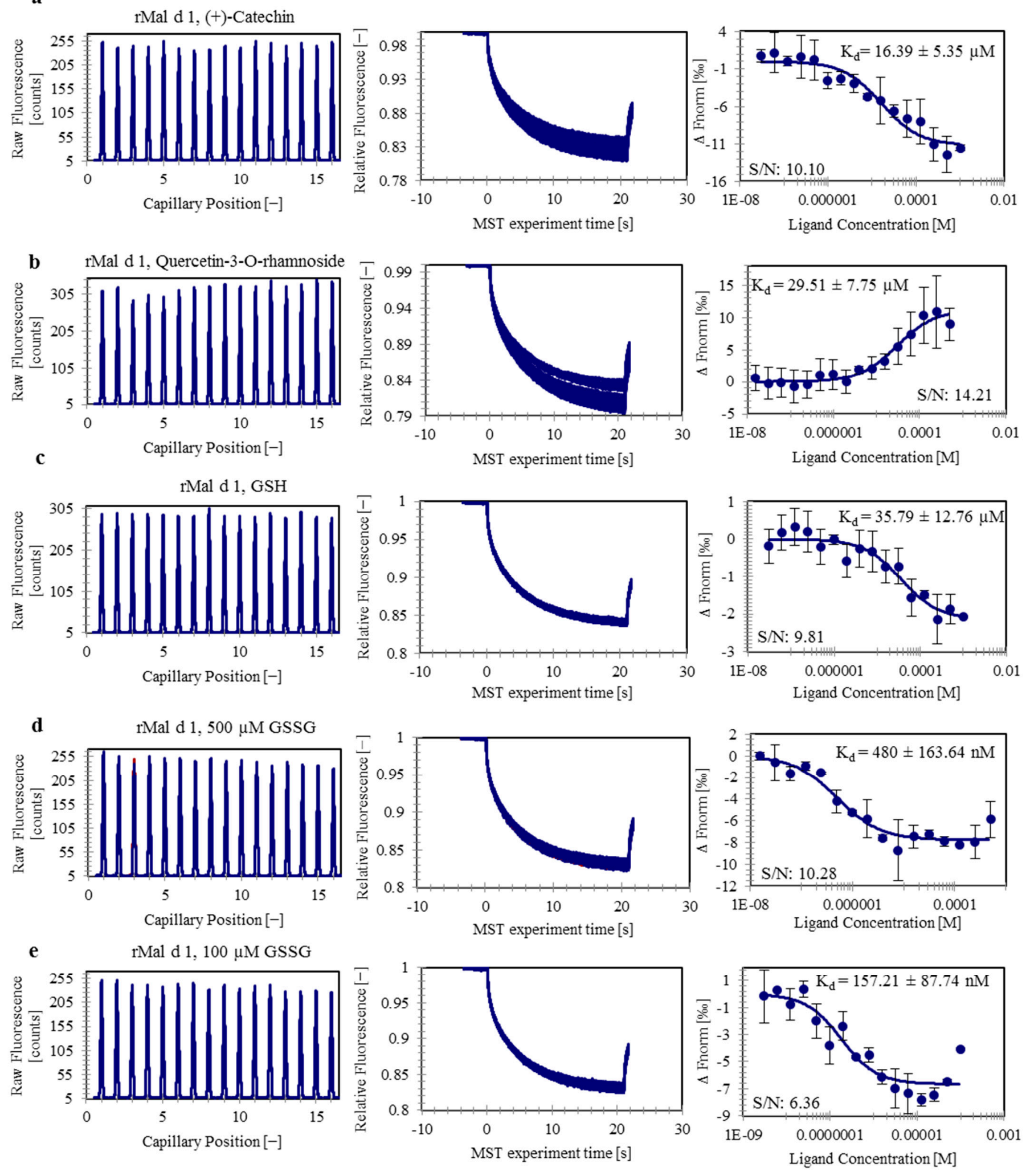

Figure 1. Capillary scan (left), MST traces (middle), and dose-response curves (right) of labeled rMal d 1 bound with catechin (a), quercetin-3-O-rhamnoside (b), GSH (c), GSSG (I) (d), and GSSG (II) (e). Error bars indicate the standard deviation between the performed technical replicates. Dissociation constants $\left(K_{d}\right)$ and signal-to-noise ratios $(S / N)$ are shown. 


\subsection{Molecular Docking of the Identified Protein-Ligand Complexes}

In addition to the biochemical binding studies, we performed molecular docking of the identified Mal d 1 ligands to the homology model of rMal d 1.02. The structure of Mal d 1 consists of a large internal cavity containing mainly hydrophobic residues, together with some polar and charged side chains forming an amphiphilic binding pocket [37]. The cavity itself can be reached by two openings, one at the N-terminal half of the long helix $\alpha 3$ and one at the side of the $\beta$-sheet between the long C-terminal helix $\alpha 3$ and strand $\beta 1$ (Figure 2 and Supplementary Figure S3).

a

$$
\mathrm{K}_{\mathrm{d}}=0.81 \mu \mathrm{M}
$$

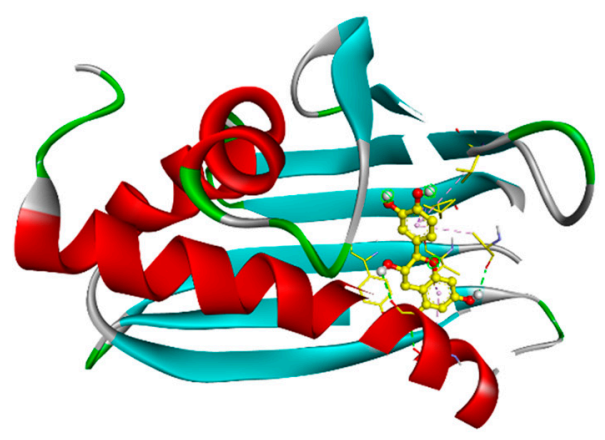

b

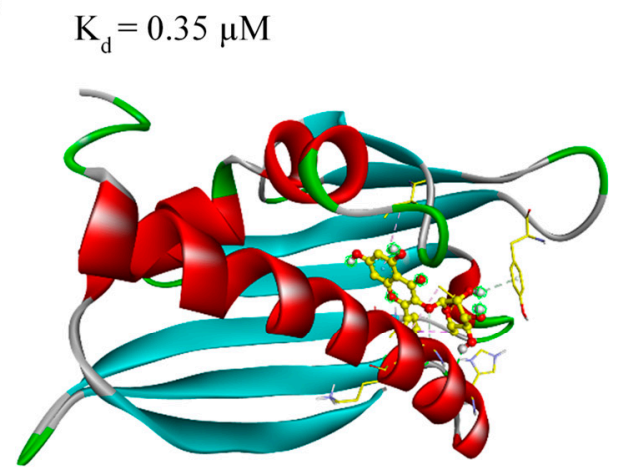

Interactions

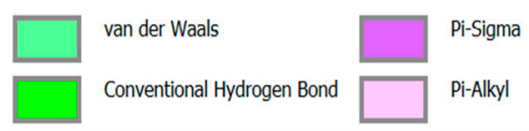

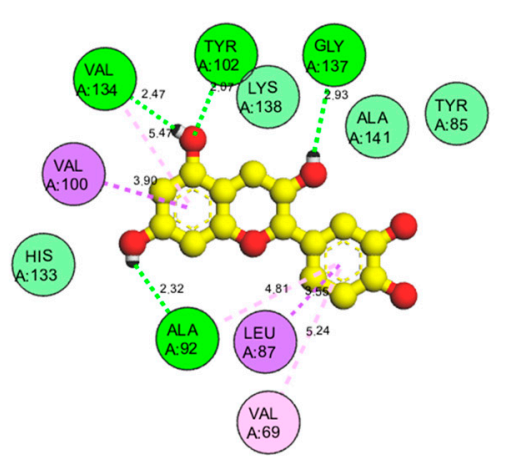

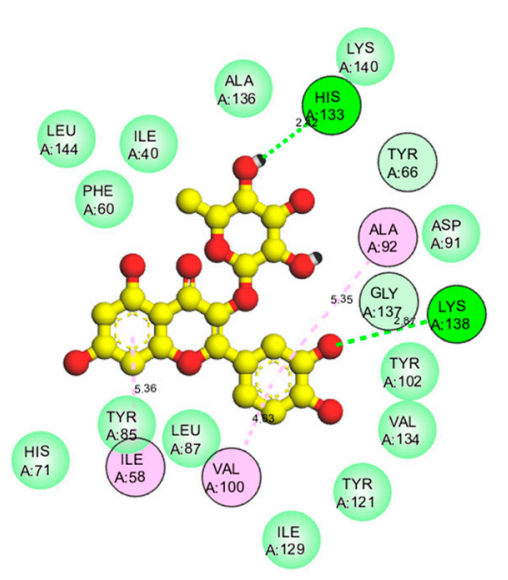

Figure 2. 3D (left) and 2D (right) interaction models of rMal d 1 in complex with (+)-catechin (a) and quercetin-3-O-rhamnoside (b).

The crystal structures of PR-10 proteins showed that the interior of the cavity is filled with ligands, solvent molecules, and buffer components [35]. The presence of water molecules in the hydrophobic cavity plays an important role in protein-ligand complexes by, for example, mediating hydrogen bonding interactions through the presence of solvent accessible polar sites. The binding of flavonoids to PR-10 proteins indicates only one valid binding site within the hydrophobic pocket $[13,20,25]$. For Fra a proteins from strawberry, it was shown that the loop regions surrounding the hydrophobic cavity are flexible and ligand binding causes conformational changes in the loop regions [13].

The structures of the rMal d 1-flavan/flavonoid complexes obtained via molecular docking (Figure 2a,b) provide possible properties of the binding mechanism. The molecules inside of the Mal d 1 cavity are stabilized by hydrophobic interactions, namely $\pi$-sigma and $\pi$-alkyl bonds, as well as polar interactions such as hydrogen bonds and van der Waals forces, creating a strong cohesive environment that stabilizes the resulting complex 
formation. The involved residues in hydrogen bonding of the catechin (Figure 2a) molecule are Ala92 (located in the loop connecting the $\beta 5$ and $\beta 6$-strands; Supplementary Figure S3), Val134 ( $\alpha 3$-helix), Tyr102 ( $\beta 6$-sheet), and Gly137 ( $\alpha 3$-helix). The (+)-epicatechin interaction is formed with the residues Phe24 (located in the loop connecting the $\alpha 1$ and $\alpha 2$-helices), Lys138 ( $\alpha 3$-helix), and Ala141 ( $\alpha 3$-helix) in the binding site of the receptor (Supplementary Figure S4a). Six interactions with Ala92 (located in the loop connecting the $\beta 5$ and $\beta 6$-strands), Val100 ( $\beta 6$-sheet), His133 ( $\alpha 3$-helix), Val134 ( $\alpha 3$-helix), Gly137 ( $\alpha 3$-helix), and Ala141 ( $\alpha 3$-helix) were identified within the (-)-epicatechin-rMal d 1 complex (Supplementary Figure $\mathrm{S} 4 \mathrm{~b})$.

The quercetin-3-O-rhamnoside complex is stabilized by hydrogen bonding created by the amino acid residues His133 ( $\alpha 3$-helix) and Lys138 ( $\alpha 3$-helix). The stability of the flavonoid complexes is also attributed to $\pi$-sigma and $\pi$-alkyl interactions between the aromatic ring of the flavonoid compound and the respective amino acid residues (Figure 2b). These hydrophobic interactions may facilitate the transfer of the molecule into the hydrophobic cavity of the protein.

The high binding affinity between rMal d 1 and GSSG can be linked in particular to the presence of seven hydrogen bonds with the respective amino acids: Phe24 (located in the loop connecting the $\alpha 1$ - and $\alpha 2$-helices), Tyr83 ( $\beta 5$-sheet), Lys86 ( $\beta 5$-sheet), Lys138 ( $\alpha 3$-helix), and Ala141 ( $\alpha 3$-helix) (Figure 3a). The latter also shows an alkyl interaction with the disulfide bond of the molecule, which helps intercalating the ligand, and thus might be responsible for the conformation of the GSSG inside of the protein cavity. The residue Tyr83 was already shown to be a key residue involved in hydrogen bonding in the Bet $\mathrm{v}$ 1a-naringenin complex $[14,25]$ and in the Bet v 1-ANS complex [20]. In contrast, the GSH complex is only stabilized by three hydrogen bonds with the respective residues, Tyr85 ( $\beta 5$ ) and Ala141 ( $\alpha 3$ ) (Figure 3b), thus explaining the lower affinity of GSH to rMal $\mathrm{d} 1$. Both complexes are further stabilized by van der Waals forces with the surrounding residues located in the interior of the cavity.

a

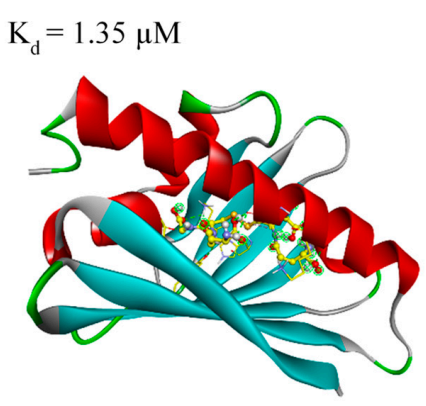

b $\quad \mathrm{K}_{\mathrm{d}}=14.35 \mu \mathrm{M}$

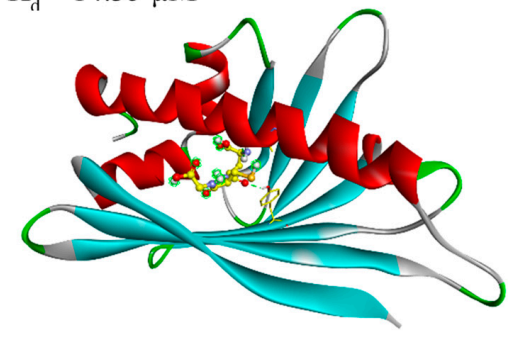

Interactions

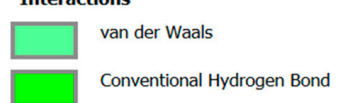

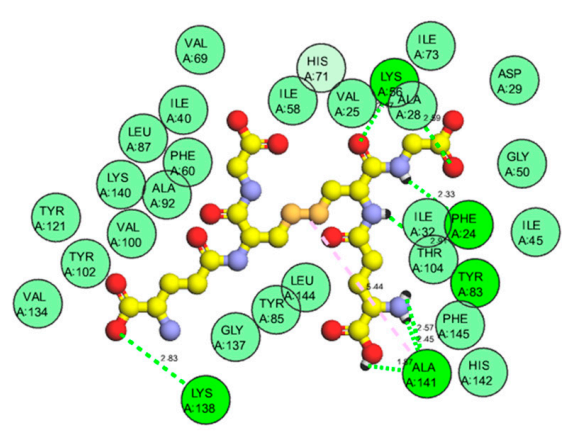

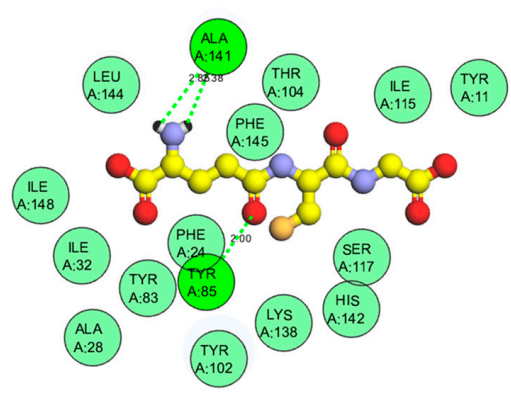

Figure 3. 3D (left) and 2D (right) interaction model of rMal d 1 in complex with GSSG (a) and $\mathrm{GSH}(\mathbf{b})$. 
Molecular docking revealed theoretical $\mathrm{K}_{\mathrm{d}}$ values of $0.81 \mu \mathrm{M}, 0.35 \mu \mathrm{M}, 0.25 \mu \mathrm{M}$, $0.69 \mu \mathrm{M}, 1.35 \mu \mathrm{M}$, and $14.35 \mu \mathrm{M}$ for catechin, quercetin-3-O-rhamnoside, (+)-epicatechin, (-)-epicatechin, GSSG, and GSH, respectively (Figures 2 and 3, Supplementary Figure S4a,b). The $\mathrm{K}_{\mathrm{d}}$ values for all ligands studied by molecular docking differed to varying degrees from the experimental data. Therefore, it should be noted that due to the large size of the protein cavity, a variety of different orientations of the docked compounds is possible, which could lead to the discrepancy between the experimental and calculated values. Although the docking experiments provided insights into the molecular binding mechanism, further studies are needed to investigate the physiological role of the detected binding interaction and to identify the exact binding region.

\section{Discussion}

\subsection{Binding of Natural Flavonoids}

The flavonoids analyzed in this study as binding partners of Mal $\mathrm{d} 1$ have been isolated from apple flesh and peel [38]. Flavonols and their glycosides are synthesized at the cytosolic side of the endoplasmic reticulum and subsequently accumulated in the central vacuole [39]. The synthesis of polyphenols and Mal d 1 is strongly affected by several stress conditions [40]. Only recently, a significant positive correlation between the content of Mal d 1 and flavan-3-ols has been reported [29]. Polyphenols exhibit antioxidative properties, thus preventing oxidative decomposition of other compounds and ensuring an oxidative equilibrium of reactive oxygen species (ROS) [41]. The binding of these compounds may not only affect their bioavailability, but could also lead to the stabilization of the protein or affect its function [13]. Previous studies have shown that the different PR-10 proteins can bind different ligands (Table 1). The hazel allergen Cor a 1 is associated with the ligand quercetin-3-O-(2-O- $\beta$-D-glucopyranosyl)- $\beta$-D-galactopyranoside [26]. In strawberry, the binding of quercetin-3-O-glucuronide, myricetin, and (+)-catechin to Fra a1E, Fra a 2, and Fra a 3 was reported with affinities of $5.3 \mu \mathrm{M}, 19.5 \mu \mathrm{M}$, and $8.9 \mu \mathrm{M}$, respectively, which demonstrated that even isoallergens can vary in their ligand binding specificities (Table 1) [13]. For the PR-10 protein Fra a 1a, transport function for intermediate compounds or products of the flavonoid biosynthesis was postulated [42]. Fra a 1 might also act as signaling component that regulates the flavonoid biosynthesis and metabolite transport through the binding of respective polyphenols [13,42]. Therefore, it is possible that Mal d 1 proteins act as transporter units that regulate the biosynthesis of polyphenols and are thus involved in defense mechanisms. In birch pollen, an isoform specific binding behavior of flavonoids was observed for Bet $v 1$, the major birch pollen allergen [14,25]. The $\mathrm{UV} / \mathrm{Vis}$ analysis revealed the binding of quercetin to Bet $\mathrm{v} 1 \mathrm{a}, \mathrm{m}$, and $\mathrm{d}$, with affinities of 9.2, 26.5, and 10.2 $\mu \mathrm{M}$, respectively (Table 1). The NMR analysis further proved the binding of quercetin-3-O-galactoside to Bet $\mathrm{v} 1 \mathrm{a}$ and $\mathrm{m}$ with $\mathrm{K}_{\mathrm{d}}$ values of less than $5 \mu \mathrm{M}$, whereas no binding was observed to Bet v $1 \mathrm{~d}$. A high affinity complex was identified for Bet $\mathrm{v}$ $1 \mathrm{a}$ and quercetin-3-O-sophoroside with a $\mathrm{K}_{\mathrm{d}}$ of $0.57 \mu \mathrm{M}$ as determined by fluorescence, suggesting a protective function against UV damage [14]. The authors also demonstrated that the sugar moiety significantly affected the affinity and specificity of the binding, and stereochemical changes of the sugar moiety in the flavonoid compound resulted in different binding affinities to Bet $\mathrm{v} 1$ isoforms. Moreover, the stereochemistry of the aglycon itself affected the binding affinity to the protein. We determined significantly different $K_{d}$ values for the diastereomers (+)-catechin/(+/-)-epicatechin (Figure 1a,b and Supplementary Figure S1a,b) and even for the enantiomers (+)-epicatechin/(-)-epicatechin (Supplementary Figure S1a,b). To date, it is unknown whether and how ligand binding and the resulting conformational change affects the allergenicity of an allergen. It is evident that although PR-10 proteins have an identical secondary structure, they still show differences in their binding behavior of physiological relevant ligands. Further studies are needed to investigate the ligand binding behavior of various low and high IgE binding Mal d 1 isoforms, as they can differ in their surface based amino acid residues of the hydrophobic cavity. 


\subsection{Relationships of PR-10 Proteins, Glutathione, and Glutathione S-Transferase Expression}

GSH is a tripeptide composed of glutamic acid, cysteine, and glycine, and can be isolated from various apple tissues, with high levels found in apple peel [36]. The thiol can undergo several redox reactions and is converted to its oxidized form, GSSG. GSSG can be reduced back by glutathione reductase using NADPH [43]. The ratio of GSH/GSSG in apple peel is reported to be up to seven, confirming that the greater part of GSH is present in the reduced state [36]. The antioxidant GSH not only takes part in storage and transport processes, but also plays a key role in the detoxification of xenobiotics and reactive oxygen species (ROS) [44]. The latter ones are induced as result of abiotic stress factors and cause severe oxidative damage, such as the inactivation of enzymes. High temperature and excessive solar radiation induce high levels of GSH in apples [45]. On the other hand, increased levels of glutathione can induce the production of plant hormones such as abscisic acid, auxin, and jasmonic acid [46]. GSH can lead to posttranslational modifications of reactive S-cysteine residues within proteins for protection against oxidation by S-glutathionylation, as was shown for the PR-10 c protein in birch [47]. Further translational modifications of Bet $\mathrm{v} 1$ isoforms have not been reported. The Sglutathiolation of rMal d 1 by GSH can be excluded because rMal d 1.02 does not contain cysteine residues (Supplementary Figure S3). Some researchers have postulated that $A B C$ transporters, such as the maize protein MRP1, are involved in the accumulation of flavonoids through the possible formation of GSH conjugates [48]. Previously it was reported that the transport of the anthocyanin, malvidin-3-glucoside into yeast vacuoles overexpressing the $\mathrm{ABC}$ grapevine protein, $\mathrm{ABCC} 1$, is dependent on free GSH [49]. A recent study confirmed that the uptake of cyanidin-3-glucoside by an $\mathrm{ABC}$ transporter is GSH-dependent, but the formation of a GSH conjugate was not shown [50]. In plants, GSH conjugates with anthocyanins or polyphenols in general have not been reported so far [48]. It is possible that GSH and GSSG act as important co-factors by binding to rMal $\mathrm{d} 1$ and navigating the transport of flavonoids to the target cell compartments of the plant, making them available to biosynthetic plant enzymes. Moreover, previous studies reported a high impact of GSH on protein synthesis, such as the transcription of chalcone synthase [51]. In plants, the formation of anthocyanins/ flavonoids, the expression of PR-10 genes, and the synthesis of PR-10 proteins are initiated in response to biotic and abiotic stress [12,35]. Since PR-10 proteins can bind flavonoids, it was suggested that they are also involved in the regulation of the flavonoid biosynthesis.

In a preliminary study, it was found that in white strawberries that were devoid of anthocyanins, the strawberry allergen Fra a 1 was downregulated, along with the enzymes chalcone synthase, dihydroflavonol reductase, and flavonone-3-hydroxylase, which are involved in the flavonoid pathway, compared to red strawberries (Figure 4) [52]. In addition, the RNAi-mediated downregulation of Fra a gene expression in transiently transformed strawberries led to decreased expression levels of flavonoid genes, and caused the formation of white transformed strawberry fruits, thus proposing that Fra a genes are of significant importance for the color formation (Figure 4) [42]. Besides, previous studies have shown that the flavonoid transport to the vacuole is driven by the flavonoid binding to glutathione-S-transferase (GST), which is considered to be a cytoplasmic flavonoid carrier protein in vivo (Figure 4) [48,53-55]. GSTs are enzymes that catalyze the conjugation of GSH to electrophilic molecules and play an important role in the transport of hydrophobic compounds (Figure 4) [56,57]. Transcriptomic analysis revealed the importance of the expression of the anthocyanidin glucosyltransferase gene and a glutathione S-transferase for the formation of anthocyanins in strawberries (Figure 4) [58]. In maize, the loss of GST function resulted in a total decrease of anthocyanins and further caused the loss of color [59]. Similarly, previous studies have further proposed that the loss of GST function can cause a reduction in anthocyanidin accumulation in concert with the loss of color development in other plants, such as MdGST in apple, VviGST4 in grape, LcGST4 in litchi, and RAP in strawberry [60-63]. More recently it was shown that the stable downregulation of the PR-10 protein Fra a 1 triggered decreased GSH concentration and lower GST expression levels in 
the transgenic fruits (Figure 4) [64]. As additional endorsement, our results demonstrate the binding of GSH and GSSG to the PR-10 protein Mal d 1, which may be of significance for the regulation of the anthocyanin/flavonoid accumulation in apples.

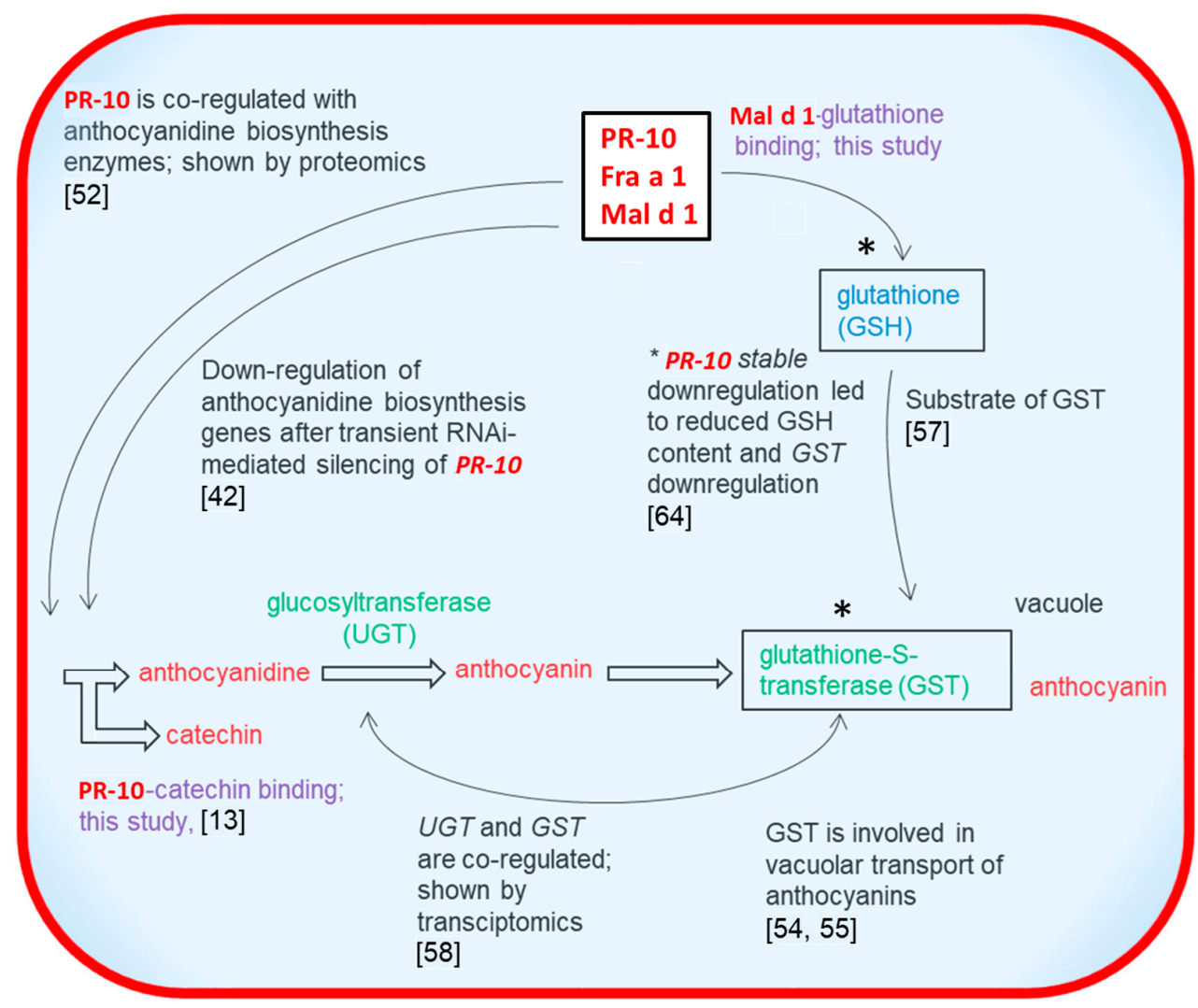

Figure 4. Relationships of PR-10 proteins, flavonoid/anthocyanin biosynthesis genes/enzymes, glutathione content, and glutathione S-transferase expression as reported and shown in this study. * PR-10 stable downregulation led to reduced GSH content and GST downregulation [64].

\subsection{Effect of Ligand Binding on the Allergenicity of the Protein}

Mal d 1 consists of various isoforms with different allergenic properties and distinct ligand binding behavior [65]. It needs to be noted that the ligands identified for recombinant rMal d 1.02 in this study are most probably not entirely the same as those of naturally occurring Mal d 1.02 and other isoforms, as different ligand binding behaviors have already been observed for Bet $\mathrm{v} 1$ isoforms [14,25]. The protein can respond in different ways to the binding of various ligands. Proteins can be stabilized and thus retain their native fold, or can be destabilized and unfold, and they are also able to form aggregates which can be associated with an altered allergenic potential $[66,67]$. Therefore, the binding of the identified ligands may be able to suppress or increase immunogenicity of rMal $\mathrm{d} 1$. The existence of hypoallergenic and hyperallergenic Mal d 1 isoforms is based on the differences in surface-based amino acid residues that are important for the formation of IgE binding epitopes [68,69]. The glycine-rich region with the key residue Glu-45 was identified as part of a conformational epitope involved in IgE binding in Bet $\mathrm{v} 1$ homologous proteins [70]. Other amino acid residues, such as Thr-10, Thr-57, Ser111, and Thr-112 were also found to play an important role in IgE binding of Mal d 1 [71,72]. In a preliminary study, the binding of zeatin to the PR-10 peach allergen Pru $\mathrm{p} 1$ did not result in any conformational changes of the glycine-rich region [73]. The binding of deoxycholate was reported to stabilize Bet v 1 without modulating its conformational epitopes, suggesting that patients are normally exposed to both ligand-bound and unbound Bet $\mathrm{v} 1$ during the sensitization phase [74]. For Bet v 1 and Fra a 1, the ligand binding led to compact protein structures with less structural flexibility $[13,75]$. Dynamic protein structures may be important for an 
optimal configuration of epitope residues and the FceRI cross-linkage [75,76]. Recently, a study of the hazelnut allergen Cor a 1.04 isoforms reported an inverse relation between the conformational flexibility and IgE binding [77]. The IgE reactivity correlated with the rigidification of the protein backbone, where the highest IgE binding was observed for Cor a 1.0401, with the most rigid backbone scaffold, whereas the lowest IgE binding potential was determined for the most structurally flexible isoform Cor a 1.0404. Different structural flexibilities have also been shown for Bet $\mathrm{v} 1$ isoforms, of which Bet $\mathrm{v} 1.0102$ has a dynamic protein structure and a low IgE binding capacity in contrast to the more rigid Bet $\mathrm{v} 1.0101$ with a high IgE reactivity [78-80]. However, it is widely unknown whether and how the ligand binding to Bet v 1, Mal d 1, and other PR-10 proteins effects the allergenicity. Further studies into the relationship between ligand binding and secondary structure changes and effects on the allergenicity of Mal d 1 are required.

\section{Conclusions}

In this study, we investigated the interaction of several natural flavonoids, as well as GSH and GSSG with recombinant rMal d 1.02, by MST in combination with molecular docking to find possible binding sites. The interactions with the $K_{d}$ values in the high nanomolar range were determined for GSSG, and in the low $\mu \mathrm{M}$ range for catechin, quercetin-3-O-rhamnoside, and GSH. While flavonoids are bound via hydrophobic and polar interactions, the binding of GSSG and GSH occurs exclusively via hydrophilic hydrogen bonds and van der Waal forces. Thus, for the first time, the binding of glutathione to a PR-10 protein was demonstrated, further substantiating the importance of this protein family for glutathione S-transferase-mediated anthocyanin accumulation in fruit. The obtained results lay the basis to analyze in detail in follow-up studies the natural ligands of Mal d 1 proteins in different plant parts, and to investigate the significance of the promiscuity of Mal d 1 ligand binding.

Supplementary Materials: The following are available online at https://www.mdpi.com/article/1 0.3390/foods10112771/s1, Figure S1: Capillary scan (left), MST traces (middle), and dose-response curves (right) of labeled rMal d 1 with (+)-epicatechin (a), (-)-epicatechin (b), glutamic acid (c), and glycine (d); Figure S2: Dose-response curves of the control experiments using labeled control peptide and cysteine (a), GSH (b) and GSSG (c); Figure S3: Amino acid sequence of recombinant rMal d 1.02; Figure S4: 3D (left) and 2D (right) interaction model of rMal d 1 in complex with (+)-epicatechin (a) and (-)-epicatechin (b).

Author Contributions: Conceptualization, S.C. and W.S.; methodology, S.C.; investigation, S.C.; resources, W.S.; data curation, S.C.; writing—original draft preparation, S.C.; writing-review and editing, W.S.; visualization, S.C.; funding acquisition, W.S. All authors have read and agreed to the published version of the manuscript.

Funding: This research was funded by the Federal Ministry of Food and Agriculture (Germany) (Project 523) grant number 313-06.01-28-1-4-IP.018.

Data Availability Statement: Data sharing not applicable.

Acknowledgments: We kindly thank Claus Schwechheimer for the use of the MST device.

Conflicts of Interest: The authors declare no conflict of interest. The funders had no role in the design of the study; in the collection, analyses, or interpretation of data; in the writing of the manuscript, or in the decision to publish the results.

\section{Abbreviations}

ANS, 1-anilino-8-naphthalene sulfonate; GSH, glutathione; GSSG, glutathione disulfide; GST, glutathione-S-transferase; IMAC, Immobilized Metal Ion Affinity Chromatography; ITC, Isothermal Titration Calorimetry; $\mathrm{K}_{\mathrm{d}}$, equilibrium dissociation constant; MST, microscale thermophoresis; PR-10, pathogenesis-related-10; ROS, reactive oxygen species; $\mathrm{SAW}$, surface acoustic wave; $\mathrm{S} / \mathrm{N}$, signal-to-noise ratio. 


\section{References}

1. Vanek-Krebitz, M.; Hoffmann-Sommergruber, K.; Laimer Da Camara Machado, M.; Susani, M.; Ebner, C.; Kraft, D.; Scheiner, O.; Breiteneder, H. Cloning and sequencing of Mal d 1, the major allergen from apple (Malus domestica), and its immunological relationship to Bet v 1, the major birch pollen allergen. Biochem. Biophys. Res. Commun. 1995, 214, 538-551. [CrossRef] [PubMed]

2. Ausukua, M.; Dublin, I.; Echebarria, M.-A.; Aguirre, J.-M. Oral Allergy Syndrome (OAS). General and stomatological aspects. Med. Oral Patol. Oral Cir. Bucal 2009, 14, e568-e572. [CrossRef]

3. Schimek, E.M.; Zwölfer, B.; Briza, P.; Jahn-Schmid, B.; Vogel, L.; Vieths, S.; Ebner, C.; Bohle, B. Gastrointestinal digestion of Bet v 1-homologous food allergens destroys their mediator-releasing, but not T cell-activating, capacity. J. Allergy Clin. Immunol. 2005, 116, 1327-1333. [CrossRef] [PubMed]

4. Bohle, B.; Zwölfer, B.; Heratizadeh, A.; Jahn-Schmid, B.; Antonia, Y.D.; Alter, M.; Keller, W.; Zuidmeer, L.; van Ree, R.; Werfel, T.; et al. Cooking birch pollen-related food: Divergent consequences for IgE- and T cell-mediated reactivity in vitro and in vivo. J. Allergy Clin. Immunol. 2006, 118, 242-249. [CrossRef]

5. Costa, J.; Bavaro, S.L.; Benedé, S.; Diaz-Perales, A.; Bueno-Diaz, C.; Gelencser, E.; Klueber, J.; Larré, C.; Lozano-Ojalvo, D.; Lupi, R.; et al. Are Physicochemical Properties Shaping the Allergenic Potency of Plant Allergens? Clin. Rev. Allerg Immunol. 2020. [CrossRef] [PubMed]

6. Van Loon, L.C.; van Strien, E.A. The families of pathogenesis-related proteins, their activities, and comparative analysis of PR-1 type proteins. Physiol. Mol. Plant Pathol. 1999, 55, 85-97. [CrossRef]

7. Hoffmann-Sommergruber, K. Plant Allergens and Pathogenesis-Related Proteins: What Do They Have in Common? Int. Arch Allergy Immunol. 2000, 122, 155-166. [CrossRef]

8. Schenk, M.F.; Cordewener, J.H.G.; America, A.H.P.; Van't Westende, W.P.C.; Smulders, M.J.M.; Gilissen, L.J.W.J. Characterization of PR-10 genes from eight Betula species and detection of Bet v 1 isoforms in birch pollen. BMC Plant Biol. 2009, 9, 24. [CrossRef] [PubMed]

9. Gajhede, M.; Osmark, P.; Poulsen, F.M.; Ipsen, H.; Larsen, J.N.; van Joost Neerven, R.J.; Schou, C.; Løwenstein, H.; Spangfort, M.D. X-ray and NMR structure of Bet v 1, the origin of birch pollen allergy. Nat. Struct. Biol. 1996, 3, 1040-1045. [CrossRef]

10. Radauer, C.; Lackner, P.; Breiteneder, H. The Bet v 1 fold: An ancient, versatile scaffold for binding of large, hydrophobic ligands. BMC Evol. Biol. 2008, 8, 286. [CrossRef]

11. Moiseyev, G.P.; Fedoreyeva, L.I.; Zhuravlev, Y.N.; Yasnetskaya, E.; Jekel, P.A.; Beintema, J.J. Primary structures of two ribonucleases from ginseng calluses. FEBS Lett. 1997, 407, 207-210. [CrossRef]

12. Besbes, F.; Franz-Oberdorf, K.; Schwab, W. Phosphorylation-dependent ribonuclease activity of Fra a 1 proteins. J. Plant Physiol. 2019, 233, 1-11. [CrossRef] [PubMed]

13. Casañal, A.; Zander, U.; Muñoz, C.; Dupeux, F.; Luque, I.; Botella, M.A.; Schwab, W.; Valpuesta, V.; Marquez, J.A. The strawberry pathogenesis-related 10 (PR-10) Fra a proteins control flavonoid biosynthesis by binding to metabolic intermediates. J. Biol. Chem. 2013, 288, 35322-35332. [CrossRef]

14. Seutter von Loetzen, C.; Hoffmann, T.; Hartl, M.J.; Schweimer, K.; Schwab, W.; Rösch, P.; Hartl-Spiegelhauer, O. Secret of the major birch pollen allergen Bet v 1: Identification of the physiological ligand. Biochem. J. 2014, 457, 379-390. [CrossRef] [PubMed]

15. Aglas, L.; Soh, W.T.; Kraiem, A.; Wenger, M.; Brandstetter, H.; Ferreira, F. Ligand Binding of PR-10 Proteins with a Particular Focus on the Bet v 1 Allergen Family. Curr. Allergy Asthma Rep. 2020, 20, 25. [CrossRef]

16. Morris, J.S.; Caldo, K.M.P.; Liang, S.; Facchini, P.J. PR10/Bet v1-like Proteins as Novel Contributors to Plant Biochemical Diversity. Chembiochem 2021, 22, 264-287. [CrossRef]

17. Casañal, A.; Zander, U.; Dupeux, F.; Valpuesta, V.; Marquez, J.A. Purification, crystallization and preliminary X-ray analysis of the strawberry allergens Fra a 1E and Fra a 3 in the presence of catechin. Acta Crystallogr. Sect. F Struct. Biol. Cryst. Commun. 2013, 69, 510-514. [CrossRef]

18. Neudecker, P.; Schweimer, K.; Nerkamp, J.; Scheurer, S.; Vieths, S.; Sticht, H.; Rösch, P. Allergic cross-reactivity made visible: Solution structure of the major cherry allergen Pru av 1. J. Biol. Chem. 2001, 276, 22756-22763. [CrossRef]

19. Romanowski, M.J.; Soccio, R.E.; Breslow, J.L.; Burley, S.K. Crystal structure of the Mus musculus cholesterol-regulated START protein 4 (StarD4) containing a StAR-related lipid transfer domain. Proc. Natl. Acad. Sci. USA 2002, 99, 6949-6954. [CrossRef]

20. Kofler, S.; Asam, C.; Eckhard, U.; Wallner, M.; Ferreira, F.; Brandstetter, H. Crystallographically mapped ligand binding differs in high and low IgE binding isoforms of birch pollen allergen bet v 1. J. Mol. Biol. 2012, 422, 109-123. [CrossRef]

21. Marković-Housley, Z.; Degano, M.; Lamba, D.; von Roepenack-Lahaye, E.; Clemens, S.; Susani, M.; Ferreira, F.; Scheiner, O.; Breiteneder, H. Crystal Structure of a Hypoallergenic Isoform of the Major Birch Pollen Allergen Bet v 1 and its Likely Biological Function as a Plant Steroid Carrier. J. Mol. Biol. 2003, 325, 123-133. [CrossRef]

22. Mogensen, J.E.; Ferreras, M.; Wimmer, R.; Petersen, S.V.; Enghild, J.J.; Otzen, D.E. The major allergen from birch tree pollen, Bet v 1, binds and permeabilizes membranes. Biochemistry 2007, 46, 3356-3365. [CrossRef] [PubMed]

23. Mogensen, J.E.; Wimmer, R.; Larsen, J.N.; Spangfort, M.D.; Otzen, D.E. The major birch allergen, Bet v 1, shows affinity for a broad spectrum of physiological ligands. J. Biol. Chem. 2002, 277, 23684-23692. [CrossRef]

24. Soh, W.T.; Aglas, L.; Mueller, G.A.; Gilles, S.; Weiss, R.; Scheiblhofer, S.; Huber, S.; Scheidt, T.; Thompson, P.M.; Briza, P.; et al. Multiple roles of Bet v 1 ligands in allergen stabilization and modulation of endosomal protease activity. Allergy 2019, 74, 2382-2393. [CrossRef] 
25. Seutter von Loetzen, C.; Jacob, T.; Hartl-Spiegelhauer, O.; Vogel, L.; Schiller, D.; Spörlein-Güttler, C.; Schobert, R.; Vieths, S.; Hartl, M.J.; Rösch, P. Ligand Recognition of the Major Birch Pollen Allergen Bet v 1 is Isoform Dependent. PLoS ONE 2015, 10, e0128677. [CrossRef]

26. Jacob, T.; von Loetzen, C.S.; Reuter, A.; Lacher, U.; Schiller, D.; Schobert, R.; Mahler, V.; Vieths, S.; Rösch, P.; Schweimer, K.; et al. Identification of a natural ligand of the hazel allergen Cor a 1. Sci. Rep. 2019, 9, 8714. [CrossRef] [PubMed]

27. Zubini, P.; Zambelli, B.; Musiani, F.; Ciurli, S.; Bertolini, P.; Baraldi, E. The RNA hydrolysis and the cytokinin binding activities of PR-10 proteins are differently performed by two isoforms of the Pru $\mathrm{p} 1$ peach major allergen and are possibly functionally related. Plant Physiol. 2009, 150, 1235-1247. [CrossRef]

28. Jerabek-Willemsen, M.; André, T.; Wanner, R.; Roth, H.M.; Duhr, S.; Baaske, P.; Breitsprecher, D. MicroScale Thermophoresis: Interaction analysis and beyond. J. Mol. Struct. 2014, 1077, 101-113. [CrossRef]

29. Romer, E.; Chebib, S.; Bergmann, K.-C.; Plate, K.; Becker, S.; Ludwig, C.; Meng, C.; Fischer, T.; Dierend, W.; Schwab, W. Tiered approach for the identification of Mal d 1 reduced, well tolerated apple genotypes. Sci. Rep. 2020, 10, 9144. [CrossRef]

30. Pace, C.N.; Vajdos, F.; Fee, L.; Grimsley, G.; Gray, T. How to measure and predict the molar absorption coefficient of a protein. Protein Sci. 1995, 4, 2411-2423. [CrossRef]

31. Gill, C.S.; von Hippel, P.H. Calculation of Protein Extinction Coefficients from Amino Acid Squence Data. Anal. Biochem. 1989, 182, 319-326. [CrossRef]

32. Trott, O.; Olson, A.J. AutoDock Vina: Improving the speed and accuracy of docking with a new scoring function, efficient optimization, and multithreading. J. Comput. Chem. 2010, 31, 455-461. [CrossRef] [PubMed]

33. Kozlovskii, I.; Popov, P. Protein-Peptide Binding Site Detection Using 3D Convolutional Neural Networks. J. Chem. Inf. Model. 2021, 61, 3814-3823. [CrossRef] [PubMed]

34. Alonso-Salces, R.M.; Ndjoko, K.; Queiroz, E.F.; Ioset, J.R.; Hostettmann, K.; Berrueta, L.A.; Gallo, B.; Vicente, F. On-line characterisation of apple polyphenols by liquid chromatography coupled with mass spectrometry and ultraviolet absorbance detection. J. Chromatogr. A 2004, 1046, 89-100. [CrossRef] [PubMed]

35. Fernandes, H.; Michalska, K.; Sikorski, M.; Jaskolski, M. Structural and functional aspects of PR-10 proteins. FEBS J. 2013, 280, 1169-1199. [CrossRef] [PubMed]

36. Li, L.; Li, X.; Ban, Z.; Jiang, Y. Variation in Antioxidant Metabolites and Enzymes of 'Red Fuji' Apple Pulp and Peel During Cold Storage. Int. J. Food Prop. 2014, 17, 1067-1080. [CrossRef]

37. Ahammer, L.; Grutsch, S.; Kamenik, A.S.; Liedl, K.R.; Tollinger, M. Structure of the Major Apple Allergen Mal d 1. J. Agric. Food Chem. 2017, 65, 1606-1612. [CrossRef]

38. Jakobek, L.; García-Villalba, R.; Tomás-Barberán, F.A. Polyphenolic characterisation of old local apple varieties from Southeastern European region. J. Food Compost Anal. 2013, 31, 199-211. [CrossRef]

39. Zhao, J.; Dixon, R.A. MATE transporters facilitate vacuolar uptake of epicatechin $3^{\prime}$-O-glucoside for proanthocyanidin biosynthesis in Medicago truncatula and Arabidopsis. Plant Cell 2009, 21, 2323-2340. [CrossRef]

40. Winkel-Shirley, B. Biosynthesis of flavonoids and effects of stress. Curr. Opin. Plant Biol. 2002, 5, 218-223. [CrossRef]

41. Treutter, D. Biosynthesis of phenolic compounds and its regulation in apple. Plant Growth Regul. 2001, 34, 71-89. [CrossRef]

42. Muñoz, C.; Hoffmann, T.; Escobar, N.M.; Ludemann, F.; Botella, M.A.; Valpuesta, V.; Schwab, W. The strawberry fruit Fra a allergen functions in flavonoid biosynthesis. Mol. Plant 2010, 3, 113-124. [CrossRef]

43. Meister, A. Glutathione metabolism and its selective modification. J. Biol. Chem. 1988, 263, 17205-17208. [CrossRef]

44. Ketterer, B.; Coles, B.; Meyer, D.J. The role of glutathione in detoxication. Environ. Health Perspect. 1983, 49, 59-69. [CrossRef]

45. Zhang, J.; Chen, S.; Li, Y.; Di, B.; Zhang, J.; Liu, Y. Effect of high temperature and excessive light on glutathione content in apple peel. Front. Agric. China 2008, 2, 97-102. [CrossRef]

46. Cheng, M.-C.; Ko, K.; Chang, W.-L.; Kuo, W.-C.; Chen, G.-H.; Lin, T.-P. Increased glutathione contributes to stress tolerance and global translational changes in Arabidopsis. Plant J. 2015, 83, 926-939. [CrossRef]

47. Koistinen, K.M.; Soininen, P.; Venäläinen, T.A.; Häyrinen, J.; Laatikainen, R.; Peräkylä, M.; Tervahauta, A.I.; Kärenlampi, S.O. Birch PR-10c interacts with several biologically important ligands. Phytochemistry 2005, 66, 2524-2533. [CrossRef]

48. Marrs, K.A.; Alfenito, M.R.; Lloyd, A.M.; Walbot, V. A glutathione S-transferase involved in vacuolar transfer encoded by the maize gene Bronze-2. Nature 1995, 375, 397-400. [CrossRef] [PubMed]

49. Francisco, R.M.; Regalado, A.; Ageorges, A.; Burla, B.J.; Bassin, B.; Eisenach, C.; Zarrouk, O.; Vialet, S.; Marlin, T.; Chaves, M.M.; et al. ABCC1, an ATP binding cassette protein from grape berry, transports anthocyanidin 3-O-Glucosides. Plant Cell 2013, 25, 1840-1854. [CrossRef] [PubMed]

50. Behrens, C.E.; Smith, K.E.; Iancu, C.V.; Choe, J.; Dean, J.V. Transport of Anthocyanins and other Flavonoids by the Arabidopsis ATP-Binding Cassette Transporter AtABCC2. Sci Rep. 2019, 9, 437. [CrossRef] [PubMed]

51. Wingate, V.P.; Lawton, M.A.; Lamb, C.J. Glutathione causes a massive and selective induction of plant defense genes. Plant Physiol. 1988, 87, 206-210. [CrossRef] [PubMed]

52. Hjernø, K.; Alm, R.; Canbäck, B.; Matthiesen, R.; Trajkovski, K.; Björk, L.; Roepstorff, P.; Emanuelsson, C. Down-regulation of the strawberry Bet $\mathrm{v}$ 1-homologous allergen in concert with the flavonoid biosynthesis pathway in colorless strawberry mutant. Proteomics 2006, 6, 1574-1587. [CrossRef] 
53. Mueller, L.A.; Goodman, C.D.; Silady, R.A.; Walbot, V. AN9, a petunia glutathione S-transferase required for anthocyanin sequestration, is a flavonoid-binding protein. Plant Physiol. 2000, 123, 1561-1570. [CrossRef] [PubMed]

54. Zhao, J. Flavonoid transport mechanisms: How to go, and with whom. Trends Plant Sci. 2015, 20, 576-585. [CrossRef] [PubMed]

55. Jiang, S.; Chen, M.; He, N.; Chen, X.; Wang, N.; Sun, Q.; Zhang, T.; Xu, H.; Fang, H.; Wang, Y.; et al. MdGSTF6, activated by MdMYB1, plays an essential role in anthocyanin accumulation in apple. Hortic. Res. 2019, 6, 40. [CrossRef]

56. Dixon, D.P.; Lapthorn, A.; Edwards, R. Plant glutathione transferases. Genome Biol. 2002, 3, REVIEWS3004. [CrossRef]

57. Strange, R.C.; Spiteri, M.A.; Ramachandran, S.; Fryer, A.A. Glutathione-S-transferase family of enzymes. Mutat. Res./Fundam. Mol. Mech. Mutagenesis 2001, 482, 21-26. [CrossRef]

58. Härtl, K.; Denton, A.; Franz-Oberdorf, K.; Hoffmann, T.; Spornraft, M.; Usadel, B.; Schwab, W. Early metabolic and transcriptional variations in fruit of natural white-fruited Fragaria vesca genotypes. Sci. Rep. 2017, 7, 45113. [CrossRef]

59. Goodman, C.D.; Casati, P.; Walbot, V. A multidrug resistance-associated protein involved in anthocyanin transport in Zea mays. Plant Cell 2004, 16, 1812-1826. [CrossRef]

60. El-Sharkawy, I.; Liang, D.; Xu, K. Transcriptome analysis of an apple (Malus $\times$ domestica) yellow fruit somatic mutation identifies a gene network module highly associated with anthocyanin and epigenetic regulation. EXBOTJ 2015, 66, 7359-7376. [CrossRef]

61. Pérez-Díaz, R.; Madrid-Espinoza, J.; Salinas-Cornejo, J.; González-Villanueva, E.; Ruiz-Lara, S. Differential Roles for VviGST1, VviGST3, and VviGST4 in Proanthocyanidin and Anthocyanin Transport in Vitis vinífera. Front. Plant Sci. 2016, 7, 1166. [CrossRef] [PubMed]

62. Hu, B.; Zhao, J.; Lai, B.; Qin, Y.; Wang, H.; Hu, G. LcGST4 is an anthocyanin-related glutathione S-transferase gene in Litchi chinensis Sonn. Plant Cell Rep. 2016, 35, 831-843. [CrossRef] [PubMed]

63. Luo, H.; Dai, C.; Li, Y.; Feng, J.; Liu, Z.; Kang, C. Reduced Anthocyanins in Petioles codes for a GST anthocyanin transporter that is essential for the foliage and fruit coloration in strawberry. J. Exp. Bot. 2018, 69, 2595-2608. [CrossRef] [PubMed]

64. Orozco-Navarrete, B.; Song, J.; Casañal, A.; Sozzani, R.; Flors, V.; Sánchez-Sevilla, J.F.; Trinkl, J.; Hoffmann, T.; Merchante, C.; Schwab, W.; et al. Down-regulation of Fra a 1.02 in strawberry fruits causes transcriptomic and metabolic changes compatible with an altered defense response. Hortic. Res. 2021, 8, 58. [CrossRef]

65. Marzban, G.; Puehringer, H.; Dey, R.; Brynda, S.; Ma, Y.; Martinelli, A.; Zaccarini, M.; van der Weg, E.; Housley, Z.; Kolarich, D.; et al. Localisation and distribution of the major allergens in apple fruits. Plant Sci. 2005, 169, 387-394. [CrossRef]

66. Breiteneder, H.; Mills, E.N.C. Molecular properties of food allergens. J. Allergy Clin. Immunol. 2005, 115, 14-23. [CrossRef]

67. Machado, Y.; Freier, R.; Scheiblhofer, S.; Thalhamer, T.; Mayr, M.; Briza, P.; Grutsch, S.; Ahammer, L.; Fuchs, J.E.; Wallnoefer, H.G.; et al. Fold stability during endolysosomal acidification is a key factor for allergenicity and immunogenicity of the major birch pollen allergen. J. Allergy Clin. Immunol. 2016, 137, 1525-1534. [CrossRef]

68. Gao, Z.; van de Weg, E.W.; Matos, C.I.; Arens, P.; Bolhaar, S.T.H.P.; Knulst, A.C.; Li, Y.; Hoffmann-Sommergruber, K.; Gilissen, L.J.W.J. Assessment of allelic diversity in intron-containing Mal d 1 genes and their association to apple allergenicity. BMC Plant Biol. 2008, 8, 116. [CrossRef] [PubMed]

69. Pagliarani, G.; Paris, R.; Iorio, A.R.; Tartarini, S.; Del Duca, S.; Arens, P.; Peters, S.; van de Weg, E. Genomic organisation of the Mal d 1 gene cluster on linkage group 16 in apple. Mol. Breed. 2012, 29, 759-778. [CrossRef] [PubMed]

70. Spangfort, M.D.; Mirza, O.; Ipsen, H.; van Neerven, R.J.J.; Gajhede, M.; Larsen, J.N. Dominating IgE-binding epitope of Bet v 1, the major allergen of birch pollen, characterized by X-ray crystallography and site-directed mutagenesis. J. Immunol. 2003, 171, 3084-3090. [CrossRef]

71. Son, D.Y.; Scheurer, S.; Hoffmann, A.; Haustein, D.; Vieths, S. Pollen-related food allergy: Cloning and immunological analysis of isoforms and mutants of Mal d 1, the major apple allergen, and Bet v 1, the major birch pollen allergen. Eur. J. Nutr. 1999, 38, 201-215. [CrossRef] [PubMed]

72. Ma, Y.; Gadermaier, G.; Bohle, B.; Bolhaar, S.; Knulst, A.; Markovic-Housley, Z.; Breiteneder, H.; Briza, P.; Hoffmann-Sommergruber, K.; Ferreira, F. Mutational analysis of amino acid positions crucial for IgE-binding epitopes of the major apple (Malus domestica) allergen, Mal d 1. Int. Arch. Allergy Immunol. 2006, 139, 53-62. [CrossRef]

73. Eidelpes, R.; Hofer, F.; Röck, M.; Führer, S.; Kamenik, A.S.; Liedl, K.R.; Tollinger, M. Structure and Zeatin Binding of the Peach Allergen Pru p 1. J. Agric. Food Chem. 2021, 69, 8120-8129. [CrossRef] [PubMed]

74. Asam, C.; Batista, A.L.; Moraes, A.H.; de Paula, V.S.; Almeida, F.C.L.; Aglas, L.; Kitzmüller, C.; Bohle, B.; Ebner, C.; Ferreira, F.; et al. Bet v 1-a Trojan horse for small ligands boosting allergic sensitization? Clin. Exp. Allergy 2014, 44, 1083-1093. [CrossRef] [PubMed]

75. Grutsch, S.; Fuchs, J.E.; Freier, R.; Kofler, S.; Bibi, M.; Asam, C.; Wallner, M.; Ferreira, F.; Brandstetter, H.; Liedl, K.R.; et al. Ligand binding modulates the structural dynamics and compactness of the major birch pollen allergen. Biophys. J. 2014, 107, $2972-2981$. [CrossRef] [PubMed]

76. Levin, M.; Davies, A.M.; Liljekvist, M.; Carlsson, F.; Gould, H.J.; Sutton, B.J.; Ohlin, M. Human IgE against the major allergen Bet v 1-defining an epitope with limited cross-reactivity between different PR-10 family proteins. Clin. Exp. Allergy 2014, 44, 288-299. [CrossRef]

77. Führer, S.; Kamenik, A.S.; Zeindl, R.; Nothegger, B.; Hofer, F.; Reider, N.; Liedl, K.R.; Tollinger, M. Inverse relation between structural flexibility and IgE reactivity of Cor a 1 hazelnut allergens. Sci. Rep. 2021, 11, 4173. [CrossRef]

78. Grutsch, S.; Fuchs, J.E.; Ahammer, L.; Kamenik, A.S.; Liedl, K.R.; Tollinger, M. Conformational Flexibility Differentiates Naturally Occurring Bet v 1 Isoforms. Int. J. Mol. Sci. 2017, 18, 1192. [CrossRef] 
79. Wagner, S.; Radauer, C.; Bublin, M.; Hoffmann-Sommergruber, K.; Kopp, T.; Greisenegger, E.K.; Vogel, L.; Vieths, S.; Scheiner, O.; Breiteneder, $\mathrm{H}$. Naturally occurring hypoallergenic Bet $\mathrm{v} 1$ isoforms fail to induce IgE responses in individuals with birch pollen allergy. J. Allergy Clin. Immunol. 2008, 121, 246-252. [CrossRef] [PubMed]

80. Smole, U.; Balazs, N.; Hoffmann-Sommergruber, K.; Radauer, C.; Hafner, C.; Wallner, M.; Ferreira, F.; Grössinger, R.; de Jong, E.C.; Wagner, S.; et al. Differential T-cell responses and allergen uptake after exposure of dendritic cells to the birch pollen allergens Bet v 1.0101, Bet v 1.0401 and Bet v 1.1001. Immunobiology 2010, 215, 903-909. [CrossRef] 